\title{
Effect of different Organic Manures on Yield and Physico-chemical Properties of Soil by Kharif Maize (Zea mays L.) on Eastern Plain Zone of Uttar Pradesh of Prayagraj Region
}

\author{
Abhishek Singh Yadav*, Tarence Thomas and Arun Alfred David \\ Department of Soil Science and Agricultural Chemistry, [Naini Agricultural Institute], \\ Sam Higginbottom University of Agriculture, Technology and Sciences, \\ Prayagraj-211007, U.P., India \\ *Corresponding author
}

\section{A B S T R A C T}

\section{Keywords}

Soil properties, nutrients, FYM, vermicompost, Bokashi, Kharif maize etc

\section{Article Info}

Accepted:

07 August 2020 Available Online: 10 September 2020
An experiment was conducted on cultivation of kharif maize with addition of different types of fertilizer and manure with different level. Vermicompost had increased the bulk and particle density, pore space, and water holding capacity, electrical conductivity and reduced $\mathrm{pH}$ and increased organic carbon content, available nitrogen, phosphorous and potassium activity in optimized treatment. Trial was conducted to obtain data the most acceptable level of Vermicompost $\left(15 \mathrm{t} \mathrm{ha}^{-1}\right)$ on the basis of physico-chemical properties of soil. Based on physico-chemical properties of soil the final optimized treatment was $\mathrm{T}_{6}$ contains Bulk density 1.65 $\mathrm{Mg} \mathrm{m}^{-3}$, Particle density $2.65 \mathrm{Mgm}^{-3}$, Pore spore $44.56 \%$, Water holding capacity $39.87 \% \mathrm{pH} 6.72$, EC $0.20 \mathrm{dSm}^{-1}$, Organic carbon $2.92 \%$, Available nitrogen $302.10 \mathrm{~kg} \mathrm{ha}^{-1}$, Available phosphorus $27.53 \mathrm{~kg} \mathrm{ha}^{-1}$ and Available Potassium $410.37 \mathrm{~kg} \mathrm{ha}^{-1}$. Addition of vermicompost continuously increased the production of kharif maize.

\section{Introduction}

Maize (Zea mays L.) is a versatile crop emerging as the third most important cereal crop next to rice and wheat in the world. Globally Corn production is galloping at 6.47 percent per year. Out of the total cereal crop production corn is growing more than 175 $\mathrm{mha}^{-1}$ across 166 countries with a production of around $1068.30 \mathrm{~m}$ tonnes. India is in the top 10 corn producing countries. India is producing about 2.48 per cent $(26.50 \mathrm{~m}$ tonnes) of the total corn produced in the world (Maize Outlook, 2018-19).

The leafy stalk of the plant produces pollen inflorescences called ears that yield kernel or seeds, which are fruits. However, little of this maize is consumed directly by humans: most is used for corn ethanol, animal feed and other maize products, such as corn starch and corn syrup. Maize kernel is an edible and nutritive part of the plant. The typical compositional range of maize is carbohydrate $(71.88 \%)$, 
protein $(8.84 \%)$, fat $(4.57 \%)$, fiber $(2.15 \%)$ and ash $(2.33 \%)$. It also contains vitamin $\mathrm{C}$, vitamin $\mathrm{E}$, vitamin $\mathrm{K}$, vitamin $\mathrm{B} 1$ (thiamine), vitamin B2 (niacin), vitamin B3 (riboflavin), vitamin B5 (pantothenic acid), vitamin B6 (pyridoxine), folic acid, selenium, N-pcoumaryl-tryptamine, and $\mathrm{N}$ ferrulyltryptamine. Potassium is a major nutrient present which has a good significance because an average human diet is deficient in it (Kumar and Jhariya, 2013). Maize germ contains about $45-50 \%$ of oil that is used in cooking, salads and is obtained from wet milling process (Orthoefer, Eastman, and List, 2003). The oil contains $14 \%$ saturated fatty acids, 30\% monounsaturated fatty acids, and $56 \%$ polyunsaturated fatty acids. The refined maize oil contains linoleic acid 54-60\%, oleic acid $25-31 \%$, palmitic acid $11-13 \%$, stearic acid 2-3\% and linolenic acid 1\% (CRA, 2006). The two main forms of vitamin $E$ present in our diet are alpha $(\alpha)$ and gamma $(\gamma)$ tocopherols. Maize oil is amongst the rich sources of these tocopherols, especially $\gamma$ tocopherol and their reported concentration was 21.3 and $94.1 \mathrm{mg} / 100 \mathrm{~g}$, respectively (Sen, Khanna, and Roy, 2006). Maize silk contains various constituents essential for our diet such as maizenic acid, fixed oils, resin, sugar, mucilage, salt, and fibers (Kumar and Jhariya, 2013).

Organic fertilizer emerged as a feasible option to concerns related to increasing food contamination. The urgency of using organic manure has been gaining ground in the escalating cost of fertilizer with every passing year and besides other inherent limitations with the use of chemical fertilizers. Organic matter in general help to regulate the biological, chemical and physical properties of the soil by acting as a "revolving nutrient fund"; and as an agent to improve soil structure, maintain tilth and minimize erosion. The accumulated organic manure is a store house of plant nutrients. The stable organic fraction (humus) adsorbs and holds nutrients in a plant available form. Organic matter releases nutrients in available form to plants upon decomposition (Alexandra and Jose, 2005).

Vermicomposting is the process by which we can convert organic waste into nutrients rich humus by using earthworms. Since then, it has taken almost a century to appreciate its important contribution in curbing inorganic pollution and improving soil productivity. Earthworm casts are usually considered to be responsible for getting a good soil structure and improving soil physical properties. Vermicompost is also considered as bio fertilizer because of its richness in humus and nitrogen fixing microorganisms. Use of organic manure has proved to be very effective and positive in crop production both as sole application as well in combination with chemical fertilizers. Reviews of current trends in organic practices have reported improved yield in rain fed areas of India, especially in drought years (Singh et al., 2001, Ramesh et al., 2005). A good proportion of plant nutrients contained in it are allowed to be wasted through improper handling, storage, use etc. as such, the organic manure prepared and used by our farmers becomes of little value in increasing crop production.

\section{Materials and Methods}

The experiments related to "Effect of Different Organic Manures on Yield and Physico-Chemical Properties of Soil by Kharif Maize (Zea mays L.), On Eastern Plain Zone of Uttar Pradesh of Prayagraj region" was carried out in there, search farm of department of Soil Science and Agricultural Chemistry which is situated six $\mathrm{km}$ away from Prayagraj city on the right bank of Yamuna river, the experimental site is located in the sub-tropical region with $25^{\circ} 24^{\prime} 23^{\prime \prime} \mathrm{N}$ 
latitude, $81^{0} 50$ '38" E longitude and at an altitude of $98 \mathrm{~m}$ above mean sea level. The area of Prayagraj district comes under subtropical belt in the South east of Uttar Pradesh, which experience extremely hot summer and fairly cold winter. The maximum temperature of the location reaches up to 46 ${ }^{0} \mathrm{C}-48{ }^{0} \mathrm{C}$ and seldom falls as low as $4{ }^{0} \mathrm{C}-5^{0} \mathrm{C}$. The relative humidity ranges between 20 to 94 percent. The average rainfall in this area is around $1013.4 \mathrm{~mm}$ annually. The soil of experimental area falls in order of Inceptisol. The soil samples were randomly collected from five different sites in the experiment plot prior to tillage operation from a depth of 0-15 $\mathrm{cm}$. The size of the soil sample was reduced by conning and quartering the composites soil sample and was air dried passed through a 2 $\mathrm{mm}$ sieve for preparing the sample for physical and chemical analysis.

\section{Procedure and Method of Bokashi Manure}

Bokashi is a Japanese word meaning "fermented organic matter." Developed in the early 1980s by Dr. TeuroHiga, a professor at the University of Ryukyus, Okinawa, Japan, the method involves layering kitchen scraps (vegetables and fruits, as well as meat and dairy scraps) with a Bokashi inoculant in a special bucket. Usually, the inoculant consists of either wheat germ, wheat bran, or sawdust combined with molasses and effective microorganisms (EM).

The Bokashi bucket has an air-tight lid and a spigot at the bottom to drain off the liquid that is produced. The liquid must be drained off to prevent the bucket from developing a somewhat foul odor, but the liquid serves as a very nutritious "bokashi tea" that can be used to fertilize houseplants.

When layered and left to sit out of direct sunlight, the mixture quickly begins to ferment, and within 10 days the fermented mixture can be dug directly into the garden or added to a traditional compost bin or pile to finish its decomposition. In essence, the bokashi process is a fermentation process rather than a traditional composting method.

\section{Soil analysis}

Soil samples were taken from $0-15 \mathrm{~cm}$ soil depth randomly prior to tillage operations, air dried and passed through $2 \mathrm{~mm}$ sieve. Then the composite soil sample was taken for mechanical and chemical analysis. Bouyoucos Hydrometer method (1927) was used for the mechanical analysis of soil to determine sand, silt and clay fraction in the sample. The texture was found sandy loam according to texture triangle USDA system.

\section{Climate and weather conditions in the experimental area}

Agro climatically, Prayagraj district represents the subtropical belt of the south east of Uttar Pradesh, and is endowed with extremely hot summer and fairly cold winter. The maximum temperature of the location ranges between $46^{\circ} \mathrm{C}$ and seldom falls below $4^{0} \mathrm{C}-5^{0} \mathrm{C}$. The relative humidity ranges between $20-94 \%$. The average rainfalls of this area are around $1100 \mathrm{~mm}$ annually.

\section{Treatment combination}

In the present study, Nine treatments were formulated viz., $\mathrm{T}_{1}, \mathrm{~T}_{2}, \mathrm{~T}_{3}, \mathrm{~T}_{4}, \mathrm{~T}_{5}, \mathrm{~T}_{6}, \mathrm{~T}_{7}, \mathrm{~T}_{8}$ and $\mathrm{T}_{9}$ Where $T_{1}$ was cultivated with 5 tonnes/ha FYM, $\mathrm{T}_{2}$ was cultivated with 10 tha $^{-1} \mathrm{FYM}, \mathrm{T}_{3}$ was cultivated with 15 tha $^{-1}$ FYM, T 4 was cultivated with 5 tha $^{-1}$ Vermicompost, $\mathrm{T}_{5}$ was cultivated with 10 tha $^{-1}$ Vermicompost, $\mathrm{T}_{6}$ was cultivated with 15 tha $^{-1}$ Vermicompost, $\mathrm{T}_{7}$ was cultivated with 5 tha ${ }^{-1}$ Bokashi manure, $\mathrm{T}_{8}$ was cultivated with 10 tha $^{-1}$ tonnes/ha Bokashi manure, $\mathrm{T}_{9}$ was cultivated with 15 tha ${ }^{1}$ Bokashi manure. 


\section{Results and Discussion}

The results obtained from the analyzed data are presented under physico-chemical properties of soil by kharif maize.

\section{Effect on Physico-chemical properties of soil by kharif maize}

In view of investigation effect on physicochemical of soil is shown in Table 1. Study showed that the maximum bulk density $(\mathrm{Mg}$ $\mathrm{m}^{-3}$ ) (1.65) was recorded in treatment $\mathrm{T}_{6}$ vermicompost manures (VC) @ $15 \mathrm{tha}^{-1}$ in the soil. The minimum bulk density (1.27) was recorded in treatment $\mathrm{T}_{1}$ farm yard manures (FYM)@ $5 \mathrm{t} \mathrm{ha}^{-1}$. The maximum particle density $\left(\mathrm{Mgm}^{-3}\right)$ of soil was found (2.65) in $\mathrm{T}_{6}$, whereas minimum particle density $\left(\mathrm{Mg} \mathrm{m}^{-3}\right)$ was (2.33) observed in treatment $\mathrm{T}_{1}$ with $5 \mathrm{t} \mathrm{ha}^{-1}$. The maximum soil pore space (\%) was (44.56) was recorded in T6 vermicompost manures (VC) @ $15 \mathrm{t} \mathrm{ha}^{-1}$. The lowest pore space (\%) (29.31) was noted with the application of $T_{1}$ farm yard manures
(FYM) @ $5 \mathrm{t} \mathrm{ha}^{-1}$. The presence of vermicompost improved the water holding capacity $(\%)$ of soil. The soil water holding capacity (\%) after crop harvest, it was observed that the highest water holding capacity (\%) (39.87) was again recorded in T6 with vermicompost manures (VC) @ $15 \mathrm{t}$ ha ${ }^{-1}$ followed by T9 bokashi manures (BK) @ $15 \mathrm{t} \mathrm{ha}^{-1}$ and lowest water holding capacity (\%) (29.57) was recorded with the application of $\mathrm{T}_{1}$ farm yard manures (FYM) @ $5 \mathrm{t} \mathrm{ha}^{-1}$. Similar observations were made by the (Pratap, D. et al., 2016) but opposite trend observed in bulk density. The soil $\mathrm{pH}$ after harvest of crop, it was observed the highest $\mathrm{pH}$ (7.42) was recorded in $\mathrm{T}_{1}$ farm yard manures (FYM) with 5 tonnes ha $^{-1}$, while lowest $\mathrm{pH}$ (6.72) was recorded with the application of $\mathrm{T}_{6}$ vermicompost manures (VC) with $15 \mathrm{t} \mathrm{ha}^{-1}$. Similar observation was by (Zhao et al., 2017). It indicates that increased in FVM, vermicompost, and bokashi manures increases the $\mathrm{EC}\left(\mathrm{dSm}^{-1}\right)$ with significant differences $(\mathrm{P}<0.5)$ (Fig. 1).

Table.1 Representation of physico-chemical properties of soil

\begin{tabular}{|c|c|c|c|c|c|c|c|c|c|c|}
\hline $\begin{array}{c}\text { Treatmen } \\
\text { ts No. }\end{array}$ & $\begin{array}{l}\text { BD } \\
(\mathbf{M g} \\
\left.\mathbf{m}^{-3}\right)\end{array}$ & $\begin{array}{l}\text { PD } \\
(\mathbf{M g} \\
\left.\mathbf{m}^{-3}\right)\end{array}$ & $\begin{array}{l}\text { PS } \\
(\%)\end{array}$ & $\begin{array}{c}\text { WHC } \\
(\%)\end{array}$ & pH & $\begin{array}{c}E C \\
\left(\mathrm{dSm}^{-1}\right)\end{array}$ & $\begin{array}{l}\text { OC } \\
(\%)\end{array}$ & $\begin{array}{c}\text { Available } \\
\text { nitrogen } \\
\left(\mathrm{kg} \mathrm{ha}^{-1}\right)\end{array}$ & $\begin{array}{c}\text { Available } \\
\text { Phosphor } \\
\text { us } \\
\left(\mathrm{kg} \mathrm{ha}^{-1}\right)\end{array}$ & $\begin{array}{c}\text { Available } \\
\text { potassium } \\
\left(\mathrm{kg} \mathrm{ha}^{-1}\right)\end{array}$ \\
\hline $\mathbf{T}_{1}$ & 1.27 & 2.33 & 29.31 & 29.57 & 7.40 & 0.67 & 0.53 & 243.27 & 20.92 & 329.99 \\
\hline $\mathbf{T}_{2}$ & 1.36 & 2.43 & 32.72 & 31.18 & 7.25 & 0.46 & 0.60 & 261.55 & 21.84 & 342.27 \\
\hline $\mathbf{T}_{3}$ & 1.42 & 2.52 & 38.18 & 32.74 & 7.20 & 0.29 & 0.65 & 288.51 & 23.41 & 343.13 \\
\hline $\mathbf{T}_{4}$ & 1.35 & 2.5 & 28.28 & 31.42 & 7.07 & 0.34 & 0.54 & 246.23 & 21.19 & 352.30 \\
\hline $\mathbf{T}_{5}$ & 1.44 & 2.61 & 34.42 & 34.08 & 6.83 & 0.25 & 0.62 & 293.27 & 23.27 & 339.43 \\
\hline$T_{6}$ & 1.65 & 2.65 & 44.56 & 39.87 & 6.72 & 0.20 & 0.72 & 302.10 & 27.53 & 410.37 \\
\hline $\mathbf{T}_{7}$ & 1.38 & 2.41 & 30.09 & 35.75 & 7.11 & 0.27 & 0.56 & 245.95 & 20.48 & 363.49 \\
\hline $\mathbf{T}_{8}$ & 1.46 & 2.49 & 35.86 & 36.87 & 6.81 & 0.24 & 0.64 & 278.57 & 23.46 & 363.49 \\
\hline $\mathbf{T}_{9}$ & 1.61 & 2.62 & 40.50 & 37.95 & 6.86 & 0.23 & 0.70 & 301.82 & 24.22 & 386.44 \\
\hline F-Test & $\mathrm{S}$ & $\mathbf{S}$ & $\mathbf{S}$ & $\mathbf{S}$ & $\mathbf{S}$ & $\mathbf{S}$ & $\mathbf{S}$ & $\mathbf{S}$ & $\mathbf{S}$ & $\mathbf{S}$ \\
\hline $\begin{array}{l}\text { C.D.at } \\
\text { 0.5\% }\end{array}$ & 0.212 & 0.199 & 7.619 & 6.112 & 0.058 & 0.063 & 0.114 & 33.004 & 0.535 & 0.929 \\
\hline S.Ed $( \pm)$ & 0.099 & 0.093 & 3.579 & 2.873 & 0.027 & 0.030 & 0.054 & 15.568 & 0.252 & 0.438 \\
\hline
\end{tabular}


Fig.1 Graphical representation of physico-chemical properties of soil

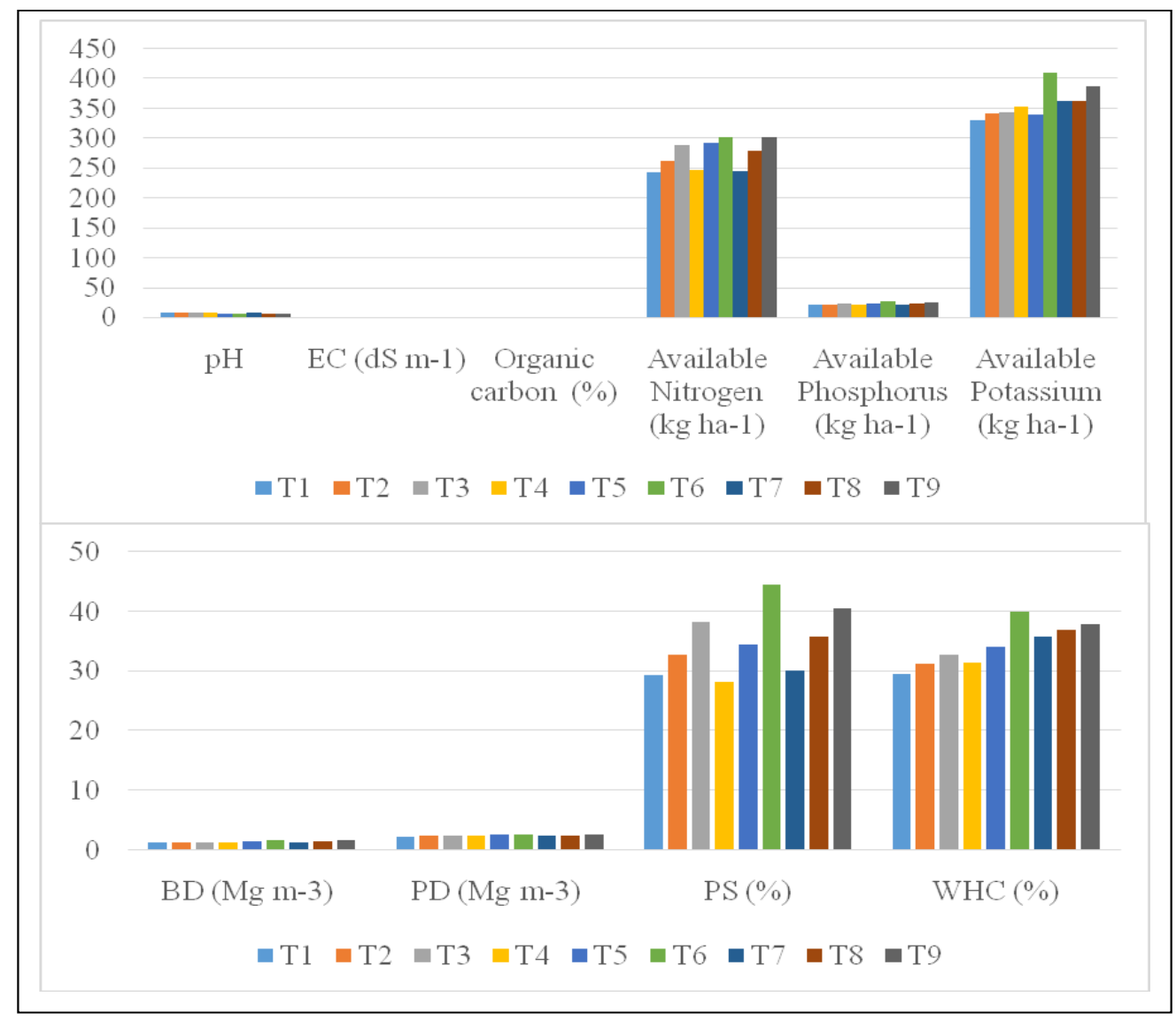

The highest EC $\left(\mathrm{dSm}^{-1}\right)$ (0.67) was recorded in $\mathrm{T}_{1}$ farm yard manures (FYM) @ $5 \mathrm{t} \mathrm{ha}^{-1}$ and lower side was noted in $\mathrm{T}_{6}(0.20)$. The results are similar to the report of (Zhao et al., 2017). Organic carbon (\%) in soil with organic manure of different treatment are $\mathrm{T}_{1}$, $\mathrm{T}_{2}, \mathrm{~T}_{3}, \mathrm{~T}_{4}, \mathrm{~T}_{5}, \mathrm{~T}_{6}, \mathrm{~T}_{7}, \mathrm{~T}_{8}$ and $\mathrm{T}_{9}$ was found to be $0.53,0.60,0.65,0.54,0.62,0.72,0.56,0.64$ and 0.70 respectively. With the increase level of vermicompost in maize crop, organic carbon was also increased of soil. Similar observations were made by the (Niranjan et al., 2010).

It was observed that available nitrogen $(\mathrm{kg}$ $\mathrm{ha}^{-1}$ ) in soil after crop harvest as affected by different treatment combination of FYM, vermicompost and bokashi manures. The effect of FYM, vermicompost and bokashi manures on Nitrogen $\left(\mathrm{kg} \mathrm{ha}^{-1}\right)$ was found to be maximum of $\left(302.10 \mathrm{~kg} \mathrm{ha}^{-1}\right)$ with the application of $\mathrm{T}_{6}$ vermicompost manures (VC) with $15 \mathrm{t} \mathrm{ha}^{-1}$ followed by $\mathrm{T}_{9}$ bokashi manures (BK) with 15 tonnes $\mathrm{ha}^{-1}, \mathrm{~T}_{5}$ vermicompost manures (VC) with $10 \mathrm{t} \mathrm{ha}^{-1}$ and $\mathrm{T}_{3}$ farm yard manures (FYM) with 15 tonnes $\mathrm{ha}^{-1}$ and the minimum nitrogen $\left(243.27 \mathrm{~kg} \mathrm{ha}^{-1}\right)$ was observed in $\mathrm{T}_{1}$ farm yard manures (FYM) with $\mathrm{t} \mathrm{ha}^{-1}$. Similar results have also been recorded by (Iqbal et al., 2013) and (Singh 2003). The data regarding Phosphorus $\left(\mathrm{kg} \mathrm{ha}^{-1}\right)$ in soil after crop harvest as affected by different treatment combination of FYM, vermicompost and bokashi manures. The effect of different level of FYM, vermicompost and bokashi manures was found to be significant. The effect of FYM, vermicompost and bokashi manures on 
phosphorus $\left(\mathrm{kg} \mathrm{ha}{ }^{-1}\right)$ was found to be maximum of $\left(27.53 \mathrm{~kg} \mathrm{ha} \mathrm{ha}^{-1}\right)$ with the application of $\mathrm{T}_{6}$ vermicompost manures (VC) with $15 \mathrm{t} \mathrm{ha}^{-1}$ followed by $\mathrm{T}_{9}$ bokashi manures (BK) with $15 \mathrm{t} \mathrm{ha}^{-1}$ and the minimum phosphorus (20.92 $\mathrm{kg} \mathrm{ha}^{1}$ ) was observed in $\mathrm{T}_{1}$ farm yard manures (FYM) with $5 \mathrm{t} \mathrm{ha}^{-1}$. (Arancon et al., 2006) reported similar effects of vermicompost on soil chemical properties on field strawberries especially increase nitrogen and phosphorus. Graph shows the available potassium $\left(\mathrm{kg} \mathrm{ha}^{-1}\right)$ in soil after crop harvest as affected by different treatment combination of FYM, vermicompost and bokashi manures. The effect of FYM, vermicompost and bokashi manures on potassium ( $\left.\mathrm{kg} \mathrm{ha}{ }^{-1}\right)$ was found to be maximum $\left(410.37 \mathrm{~kg} \mathrm{ha}^{-1}\right)$ while minimum potassium (329.99 $\mathrm{kg} \mathrm{ha}^{-1}$ ) was observed in $\mathrm{T}_{1}$ farm yard manures (FYM) with $5 \mathrm{t} \mathrm{ha}^{-1}$.

The results agreed the report of (Azarmi et al., 2008) showed that vermicompost had beneficial effects on soil chemical properties on tomato field, especially caused significant increase of organic carbon, available nitrogen, phosphorus and potassium. Similar results were noted by (Ghanshyam et al., 2010), who reported that available $\mathrm{N}$ and $\mathrm{P}$ status of soil after harvesting of preceding green gram were significantly greater than those in the untreated plots.

In conclusion the FYM, vermicompost and bokashi manure treatment at different level dose of organic manure application can increase the physico-chemical properties and also increase the yield of kharif maize. Results of soil analysis based on physicochemical properties showed that an increase in soil properties with increased levels of different types of manure. The use of vermicompost as the organic manure significantly improved the basic soil physicochemical properties, mineral nutrient, and biological properties, and it also increased maize yield, and improved fruit quality of maize.

\section{Acknowledgement}

The authors are grateful to the Hon'ble Vice chancellor SHUATS, Department of Soil Science and Agricultural Chemistry, Naini Agriculture Institute, for taking their keen interest and encouragement to carry out the research work.

\section{References}

Alexandra, B. and José, B. (2005) The importance of soil organic matter, key to drought-resistant soil and sustained food and. production. Food and Agriculture Organization, soils Bulletin80.

Arancon, N. Q., Edwards, C. A. and Bierman, P. (2006) Influences of vermicompost's on field strawberries: Part 2. Effects on soil microbiological and chemical properties. Bioresource Technology. 97: 831-840.

Azarmi, R., Giglou, M. T. and Taleshmikail, R. D. (2008) Influence of vermicompost on soil chemical and physical properties in tomato (Lycopersicon esculentum) field. African Journal of Biotechnology. 7(14): 2397-2401.

Ghanshyam, Kumar, R. and Jat, R. K. (2010) Productivity and soil fertility as effected by organic manures and inorganic fertilizers in green gram (Vigna radiata)- wheat (Triticum aestivum) system. Indian Journal of Agronomy. 55(1):16-21.

Iqbal, A., Raza, A., Akbar, N., Abbas, R. N. and Khan, H. Z. (2013) Integrated nitrogen management studies in forage maize. American-Eurasian J. Agric. and Environ. Sci., 14(8): 744-747.

Kumar, D. and Jhariya, N. A. (2013) Nutritional, medicinal and economical- 
importance of corn: A mini review. Research Journal of Pharmaceutical Sciences. 2:7-8.

Maize outlook (2018-19) Agricultural market intelligence centre, PJTSAU, 1-3.

Niranjan, R. K., Amit, P., Gupta, H.K., Verma, M. R. and Singh, G. (2010) Influences of vermicompost on soil chemical properties and nutrient uptake by Mung bean (Vigna radiata L.). International Journal of Recent Scientific Research. 04:092-097.

Orthoefer, F., Eastman, J., and List, G. (2003) Corn oil: composition, processing and utilization. In P. J. White, L. A. Johnson (Eds.), Corn: Chemistry and technology (2nd ed.) St. Paul, MN: American
Association of Cereal Chemists. 671693.

Ramesh, P., Singh, M. and Subbarao, A. (2005) Organic Farming: Its relevance to the Indian context. Current Science. 88: 561-569.

Sen, C. K., Khanna, S., and Roy, S. (2006) Tocotrienols: Vitamin E beyond to copherols. Life Sciences. (http://dx.doi.org/10.1016/j.lfs.2005.12. 001) 78: 2088-2098.

Singh, G. R., Chaure, N. K. and Parihar, S. S. (2001) Organic Farming for sustainable agriculture. Indian Farmer Journal. 52: 12-17.

\section{How to cite this article:}

Abhishek Singh Yadav, Tarence Thomas and Arun Alfred David. 2020. Effect of different Organic Manures on Yield and Physico-chemical Properties of Soil by Kharif Maize (Zea mays L.) on Eastern Plain Zone of Uttar Pradesh of Prayagraj Region. Int.J.Curr.Microbiol.App.Sci. 9(09): 634-640. doi: https://doi.org/10.20546/ijcmas.2020.909.080 